\title{
Timber frame houses resistant to dynamic loads - seismic analysis
}

\author{
Marcin Szczepański ${ }^{1,}$, Wojciech Migda ${ }^{2}$, \\ ${ }^{1}$ Gdansk University Of Technology, Narutowicza 11/12, 80-233 Gdańsk Department of Civil and \\ Environmental Engineering; marszcze@pg.gda.pl \\ ${ }^{2}$ Gdansk University Of Technology, Narutowicza 11/12, 80-233 Gdańsk Department of Civil and \\ Environmental Engineering; wmigda@pg.gda.pl
}

\begin{abstract}
The aim of the article is to present results of seismic analysis results of two real-sized timber frame buildings subjected to seismic excitations. The first model was insulated with mineral wool, the second one with polyurethane foam. Technology and specifications involved in both models construction is based on the previously conducted experimental research on timber frame houses, including wall panels tests, wall numerical models and study on material properties and precisely reflect results of the those research. During the seismic analysis reference node located in buildings were selected. In selected node displacement values were measured and compared between two analyzed models. The results of the numerical analysis presented in the article indicate that the application of polyurethane foam for a skeleton filling of the timber-frame building leads to the increase in stiffness as well as damping of the whole structure, which results in a considerable increase in the seismic resistance of the structure.
\end{abstract}

\section{Introduction}

While analysing the technology of single-family houses resistant to dynamic loads, including seismic excitations and traffic impact[1-4] it becomes evident that timber is one of the best materials for that kind structures. Development of different solutions is further escalated with the spread of ecology and energy-efficient related topics, as well as functionality of such structures as building passive houses. Timber frame buildings constructed with accordance to the technological viewpoint are usually quite resistant to dynamic effects, including earthquakes [5]. Timber-based boards, like OSB (multifunctional or $\mathrm{OSB} / 3$ oriented strand board) are the most frequently elements for covering of ceilings, roofs as well as most of walls of the timber frame houses. These boards have very good durability properties, which allow us to stiffen the whole structure and reduce the forces occurring during dynamic excitations [6 - 9]. Data gathered in Japan and South America shows that timber frame houses can often withstand mining shakes and even catastrophic earthquakes with just minor damage [5].

\footnotetext{
${ }^{*}$ Corresponding author: marszcze@pg.edu.pl
} 
Thermal insulation is extremely important in relation to the timber frame house building technology $[10,11]$. Materials used for thermal insulation of such structures may be incompatible with the timber frame or may significantly stiffen it due to their parameters [12]. Testing mechanical parameters of different insulation materials proves their usability for insulation and stiffening purposes. Mineral wool is the most popular insulation material, not co-operating mechanically with the timber frame. Poliurethan foam is another, different kind of insulation material. Due to the closed cell structure and mechanical properties polyurethane foam increases the rigidity of the timber frame elements [12].

The aim of the article is to present the results of dynamic numerical analysis focused on earthquake-induced response of two timber frame buildings insulated with mineral wool and with polyurethane foam. Both numerical models show identical geometrical properties and differ only in the used thermal insulation material.

\section{Experimental and numerical studies of exterior walls models}

Two models of exterior walls were constructed using two different insulation materials to verify the behaviour through the experimental study (see [12] for details) Both experimental models were made in the traditional technology of timber houses. One of them was filled with mineral wool and the other with polyurethan foam.

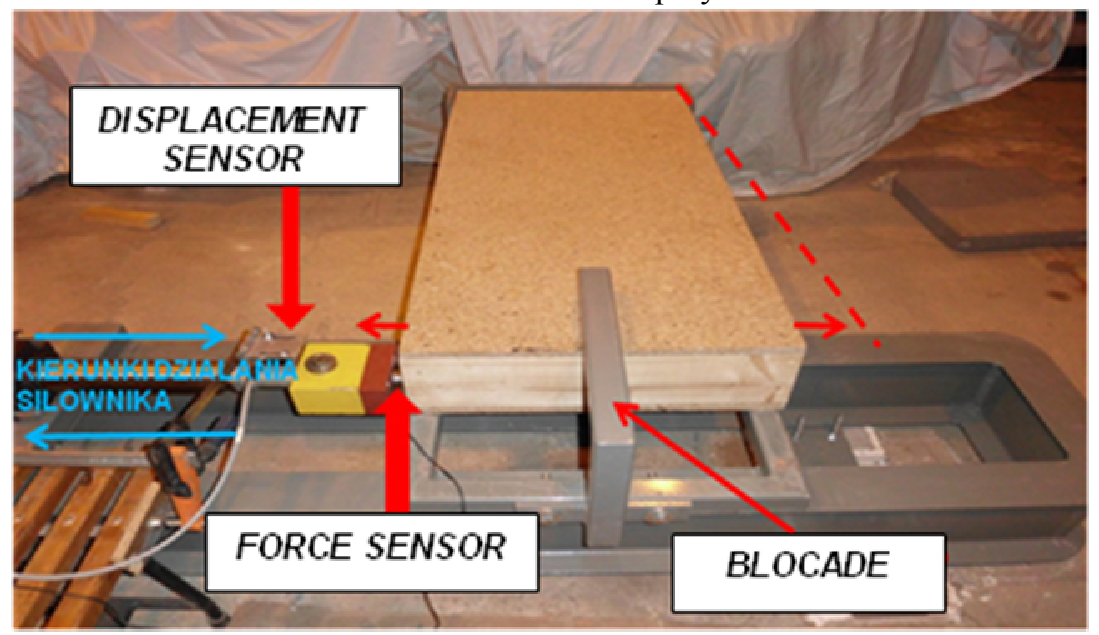

Fig. 1. View of the experiment setup with mounted specimen [13]

A specially designed test setup was used in the experimental study (Fig. 1). The tests were performed for the following excitation frequencies: $0.5 \mathrm{~Hz}, 1.0 \mathrm{~Hz}, 2.0 \mathrm{~Hz}$ and $5.0 \mathrm{~Hz}$, for various values of displacement. The hysteresis loops were obtained for different displacements for a given frequency excitation. On the basis of the experimental results, numerical models of two wall elements were prepared. The results of numerical analysis were consistent with the results from the experimental study confirming the accuracy of the models created [12]. 


\section{Numercial models of timber frame houses - dynamic analysis}

A single-storey timber frame building of the following parameters:

- storey height: $2.80 \mathrm{~m}$

- length of the building: $12.0 \mathrm{~m}$

- width of the building: $12.0 \mathrm{~m}$

was taken into consideration in the numerical analysis (see numerical models at Fig. 2 and Fig. 3). A building timber frame was made of a conifer timber of $\mathrm{C} 24$ class surrounded with OSB3 boards on both sides. Numerical model 1 was created based on the assumption that the structure is insulated with mineral wool, while numerical model 2 was dedicated to building insulated with polyurethan foam. The model of the real structural model was created based on numerical models of exterior walls which, in turn, were verified based on experimental study [12].

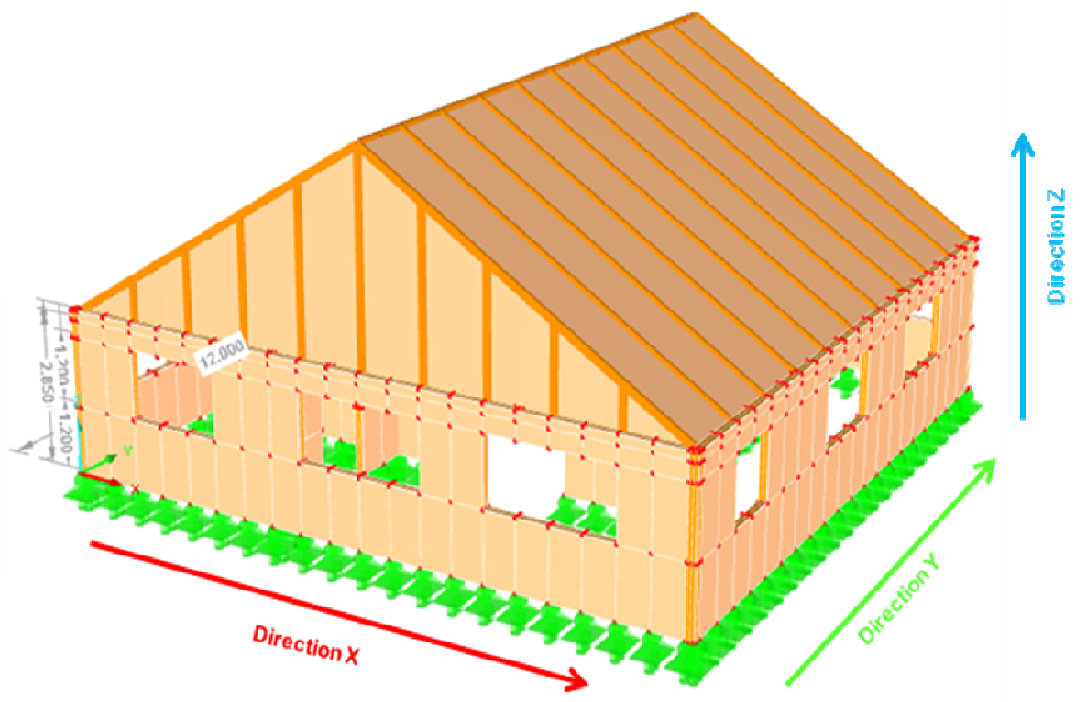

Fig. 2. Numerical model of the building showing a typical wall element

The natural vibrations modes, together with the corresponding frequencies, were obtained as the results of the modal analysis of the timber frame buildings filled with mineral wool and polyurethane foam. The examples of the results in the form of the second natural vibration modes are shown in Fig. 3 and Fig. 4. The values of the first 10 natural frequencies are also summarized in Table 1 (see [13] for simmilar procedure). 

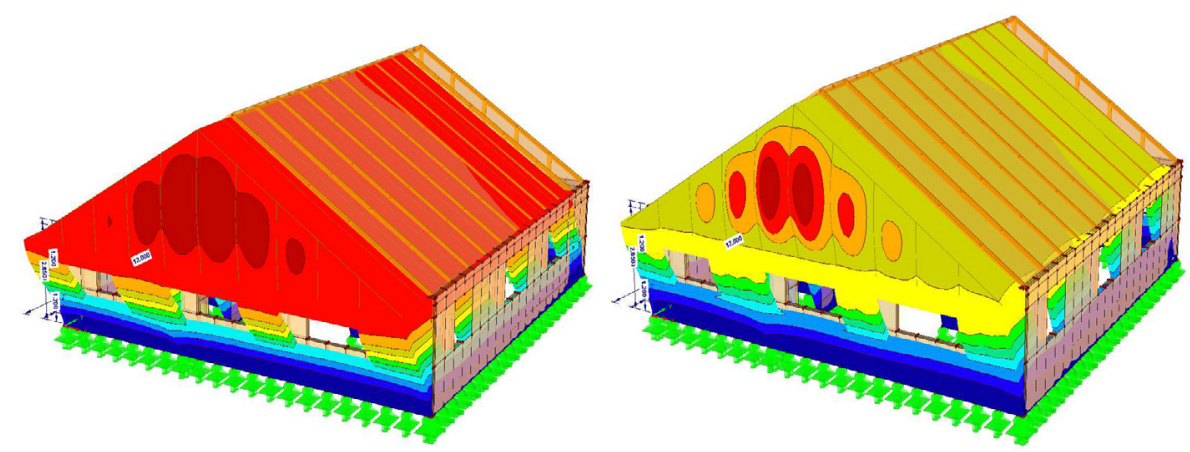

Fig. 3. Second natural vibration mode for both models (mineral wool first from the left and polyurethane foam second), second natural frequency:

$$
f_{1}=1.975 \mathrm{~Hz}, f_{2}=3,358 \mathrm{~Hz}
$$

Table 1. Natural Frequencies for first 3 Natural Vibration Modes

\begin{tabular}{|c|c|}
\hline $\begin{array}{c}\text { Model filled with mineral } \\
\text { wool (Hz) }\end{array}$ & $\begin{array}{c}\text { Model filled with } \\
\text { polyurethane foam }(\mathbf{H z})\end{array}$ \\
\hline 1,89 & 3,136 \\
\hline 1,975 & 3,358 \\
\hline 2,543 & 4,337 \\
\hline
\end{tabular}

The results of modal analysis of both models show that the timber frame model insulated with polyurethane foam displays larger stiffness.

\section{Numercial analysis of the response of the building under seismic excitation}

The next stage of the study was devoted to the numerical analysis focused on structural behaviour under seismic excitation. During the analysis, both models were subjected to the Loma Prieta earthquake of October 17th 1989 (see Table 2.) acting in all three directions simultaneously. Visualisation of reference node no. 2177 selected to analysis shown in Fig. 5.

The displacement time histories in all three directions for selected node no. 2177 of model insulated with mineral wool are shown in Fig. 6. The corresponding results for the model with polyurethane foam are presented in Fig. 7. The detailed comparison between the peak displacements at node no. 2177 for both models in all three directions is shown in Tables 3 - 5 .

Tabel 2. Earthquake parameters

\begin{tabular}{|c|c|c|c|c|c|}
\hline Earthquake & Date & Magnitude & $\begin{array}{c}\text { Measuring } \\
\text { station }\end{array}$ & Component & $\begin{array}{c}\text { Exstreme acceleration } \\
\text { value }\left[\mathrm{m} / \mathrm{s}^{2}\right]\end{array}$ \\
\hline \multirow{3}{*}{ Loma Prieta } & \multirow{3}{*}{17.10 .1989} & \multirow{3}{*}{6,9} & \multirow{3}{*}{$\begin{array}{c}\text { Capitola - } \\
\text { Fire } \\
\text { Station }\end{array}$} & NS & 3,907 \\
\hline & & & & EW & 4,629 \\
\hline & & & & UD & 5,000 \\
\hline
\end{tabular}




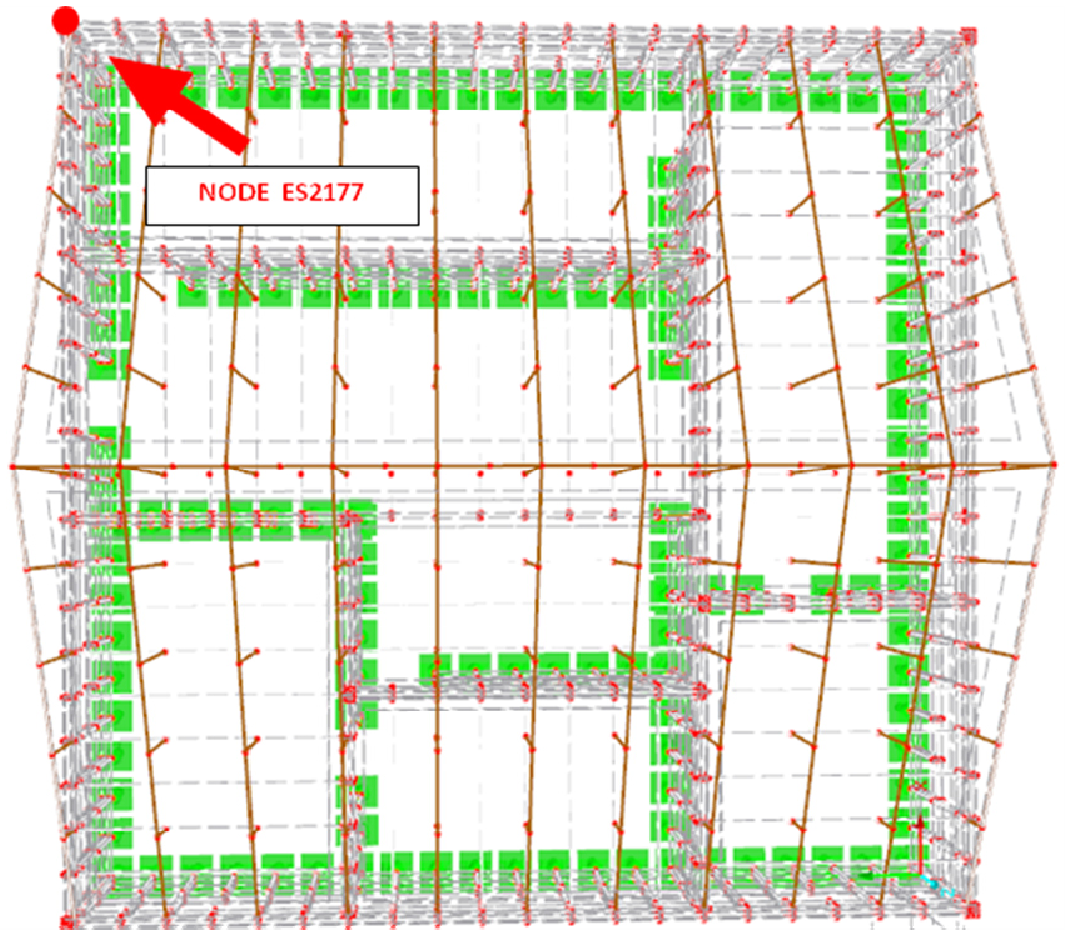

Fig. 4. Visualisation of refence node selected to analysis 
a)

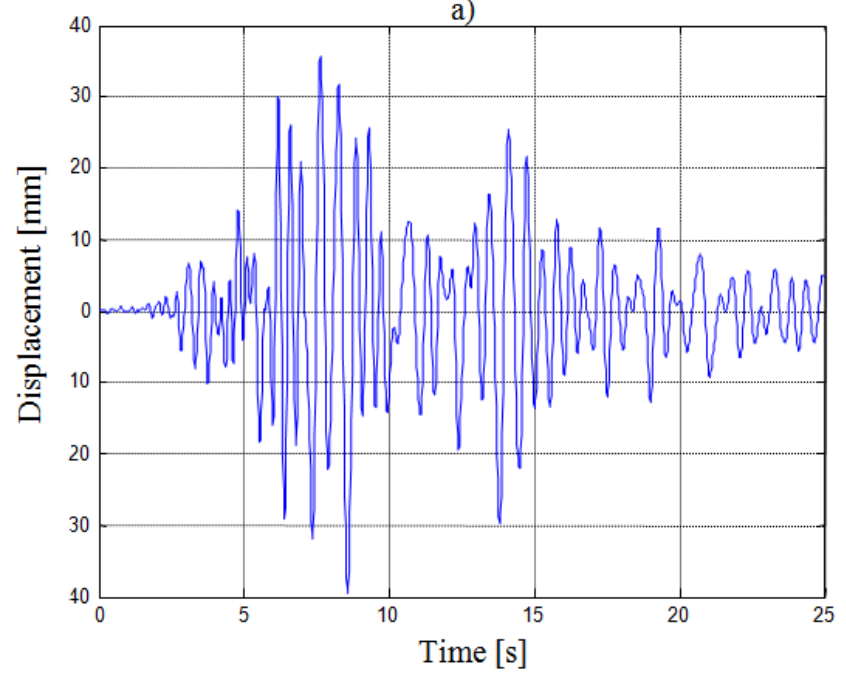

b)

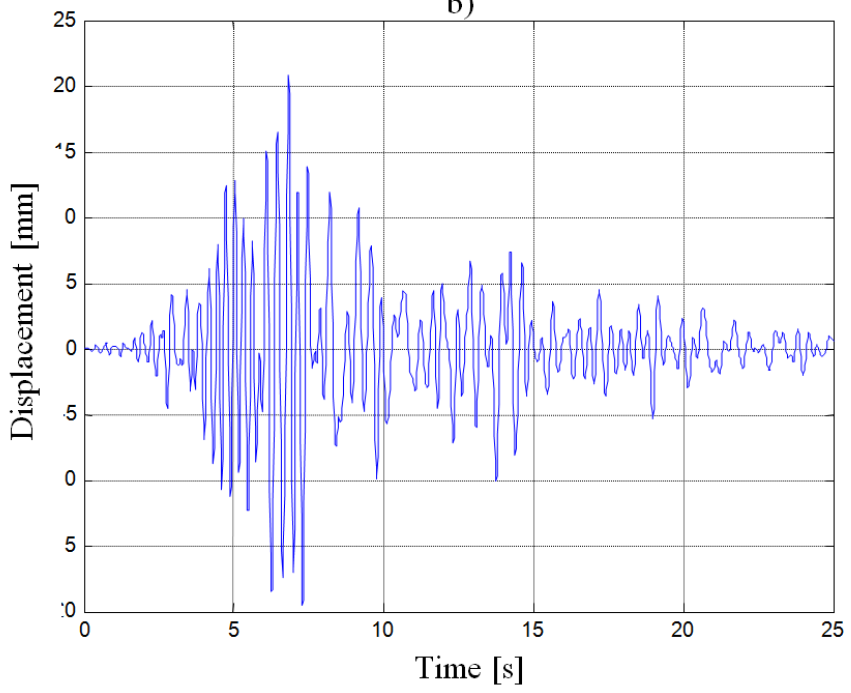

Fig. 5. Displacement time histories for both models - node 2177 direction: $x$ (a- mineral wool; b- polyurethane foam)

Tabela 3 Peak displacements at node no. 1 - x direction

\begin{tabular}{|c|c|c|}
\hline $\begin{array}{c}\text { Model with mineral } \\
\text { wool [mm] }\end{array}$ & $\begin{array}{c}\text { Model with polyurethane } \\
\text { foam [mm] }\end{array}$ & $\begin{array}{c}\text { Reduction } \\
\text { (\%) }\end{array}$ \\
\hline $40,10 \mathrm{~mm}$ & $20,50 \mathrm{~mm}$ & 48,8 \\
\hline
\end{tabular}

Tabela 4 Peak displacements at node no. 1 - y direction

\begin{tabular}{|c|c|c|}
\hline $\begin{array}{c}\text { Model with mineral } \\
\text { wool }[\mathbf{m m}]\end{array}$ & $\begin{array}{c}\text { Model with polyurethane } \\
\text { foam [mm] }\end{array}$ & $\begin{array}{c}\text { Reduction } \\
\mathbf{( \% )}\end{array}$ \\
\hline $34,50 \mathrm{~mm}$ & $12,50 \mathrm{~mm}$ & 63,7 \\
\hline
\end{tabular}


Tabela 5 Peak displacements at node no. 1 - z direction

\begin{tabular}{|c|c|c|}
\hline $\begin{array}{c}\text { Model with mineral } \\
\text { wool [mm] }\end{array}$ & $\begin{array}{c}\text { Model with polyurethane } \\
\text { foam [mm] }\end{array}$ & $\begin{array}{c}\text { Reduction } \\
\mathbf{( \% )}\end{array}$ \\
\hline $2,80 \mathrm{~mm}$ & $1,45 \mathrm{~mm}$ & 48,2 \\
\hline
\end{tabular}

\section{Conclusions}

The dynamic numerical analysis focused on the response of timber frame house under seismic excitation has been presented in this paper. The results of the study confirm that using a polyurethan foam leads to much lower displacement values comparing to the case when the mineral wood is applied as an insulation material. The reductions of peak values for node no. 2177 is as large as $48,8 \%, 63,7 \%$ and $48,2 \%$ for $x, y$ and $z$ direction, respectively. It is especially important considering the fact that the reduction in displacements is directly related to the reduction in damage of structures exposed to dynamic loads (see also [13]). Therefore, based on the results, a positive outcome of using polyurethane foam insulation instead of mineral wool in timber frame structures exposed to seismic excitations is well observed.

\section{References}

[1] T. Toratti, Seismic Design of Timber Structures, FEMA, 1994.

[2] A.K. Chopra, Dynamic of Structures: Theory of Applications to Earthquake Engineering, Prentice-Hall, USA, 1995.

[3] ECS, Eurocode 8: Design Provisions for Earthquake Resistance of Structures. Brussels, European Committee for Standardization, Belgium, 1998.

[4] A. Jakubczyk-Gałczyńska, A. Kristowski, R. Jankowski, Comparing the effectiveness of ANNs and SVMs in forecasting the impact of traffic-induced vibrations on building. Geodetic Congress (BGC Geomatics), Gdańsk, Poland, 121-125 (2017)

[5] J-M. Seo, I-K. Choi, and J-R. Lee, "Experimental study on the aseismic capacity of a wooden house using shaking table," Earthquake Engineering and Structural Dynamics, vol. 28, pp. 1143-1162, 1999.

[6] J. Kiyono and A. Furukawa, "Casualty occurrence mechanism in the collapse of timber-frame house during an earthquake," Earthquake Engineering and Structural Dynamics, vol. 33, pp. 1233-1248, 2004.

[7] J. Vessby, Analysis of shear walls for multi-storey timber buildings, Linnaeus University Dissertations, No 45/2011, 2011.

[8] S. Pei and J.W Van de Lindt, "Coupled shear-bending formulation for seismic analysis of stacked wood shear wall systems," Earthquake Engineering and Structural Dynamics, vol. 38, pp. 1631-1647, 2009.

[9] R. Zarnic and B. Dujic, "Study of rateral resistance of massive X-lam wooden wall system subjected to horizontal loads," Earthquake Engineering on Timber Structures, Portugal 2006.

[10] W. Nitka, Mój dom z drewna, Centrum Informacyjne Lasów Państwowych, Warszawa, 2010.

[11] Radziszewska-Zielina E.: Analiza porównawcza parametrów materiałów termoizolacyjnych mających zastosowanie jako izolacja ścian zewnętrznych. Konferencja Naukowo-Techniczna Inżynieria Przedsięwzięć Budowlanych, nr 4, s. 32-37, Kraków 2014.

[12] M. Szczepański, W. Migda, and R. Jankowski, "Construction technology of timber-frame houses resistant to dynamic loads - study on models of exterior walls", Advances in Science and Technology - Research Journal, vol. 9, no. 28, pp. 75-80, 2015.

[13] M. Szczepanski, W. Migda, R. Jankowski, Modal analysis of real timber frame houses with different insulation materials. Advances in Science and Technology Research Journal, vol. 10, 215-221 (2016) 